\title{
Analysis of Awareness Level of Agricultural Insurance among the Stakeholders in Punjab
}

\author{
Ahmad Mubasher Wahab Zada, Lopamudra Mohapatra* and Anupam Anand
}

Department of Extension Education, Punjab Agricultural University, Ludhiana, Punjab, India

*Corresponding author: lopa.lopapau83@yahoo.co.in (ORCID ID: 0000-0002-0922-7004)

Received: $14-04-2019$

Revised: $19-07-2019$

Accepted: 21-08-2019

\begin{abstract}
The flagship program Pradhan Mantri Fasal Bima Yojana was launched on $13^{\text {th }}$ January 2016 that aims to improve the productivity and earnings of farmers and Weather Based Crop Insurance Scheme (WBCIS) aims to mitigate the hardship of the insured farmers against the likelihood of financial loss on account of anticipated crop loss resulting from adverse weather conditions which was restructured and launched by GOI in March, 2016. Both the schemes PMFBY \& MWBCIS have not been implemented in the state of Punjab but there have been wide publicity of both the schemes at district level camps organised by the Krishi Vigyan Kendra (KVK) of Indian Council of Agricultural Research (ICAR). Keeping in view this study analyses the awareness level of these two schemes were among the three stakeholders viz; scientists, extensionists and farmers. Majority of the scientists aware about of the features of PMFBY\& WBCIS like coverage of crop, risk coverage whereas less aware about the post-harvest coverage losses. Only 37 percent of scientists were aware about the insurance unit to be village panchayat where as 28 percent of scientists were aware that the sum insured in same for loanee and non loanee farmers and similar trend of awareness was also found for the extensionists. Almost more than half of the progressive farmers were aware regarding the various aspects of PMFBY. There is a need to make the famers aware about crop/weather insurance through awareness programme. Insurance education can be incorporated into various training programmes organized on risk management.
\end{abstract}

\section{Highlights}

(0 The study analyses the awareness of farmers, scientists and extensionists regarding the various features of India's two leading agricultural insurance scheme viz. PMFBY and WBCIS.

Keywords: Awareness, Pradhan Mantri Fasal Bima Yojana, Stakeholders, Agricultural Insurance

Agricultural risks refer to the weather variability, frequent natural disasters, uncertainties in yields and prices, weak rural infrastructure, imperfect markets and inadequate and sub-optimal financial services including the limited span and design of risk mitigation instruments such as credit and insurance (Rao and Bockel, 2008). Whereas one of the most advocated risk mitigation strategies implemented by the Government of India nationwide is agricultural insurance and it has been eyed as one of the seven strategies which shall increase the farmers' income. Agricultural insurance is an effective mechanism for reducing the losses, farmers suffer due to natural calamities such as floods, droughts, and outbreaks of pests and diseases. It enables farmers to obtain credit and financing for investment in new technologies, tools, and equipment to enhance and sustain their productive capacity. Weather-based crop insurance aims at mitigating the hardship of the insured farmers against the likelihood of financial loss on account of anticipated crop loss resulting from incidence of adverse conditions of weather parameters like rainfall, temperature, frost, humidity, etc. (Biswas et al. 2009). One of the flagship program launched on 13th January 2016 that aims to improve the productivity and earnings of farmers is 
Pradhan Mantri Fasal Bima Yojana. Weather Based Crop Insurance Scheme (WBCIS) aims to mitigate the hardship of the insured farmers against the likelihood of financial loss on account of anticipated crop loss resulting from adverse weather conditions relating to rainfall, temperature, wind, humidity etc. It has been restructured and launched by GOI in March, 2016. Punjab state of Indian subcontinent is the largest surplus producer of food grain contributing 11 per cent of national rice production and 20 per cent of national wheat production in 2016 (Anonymous 2010). Due to unregulated use of water and heavy subsidies on power, there has been a tendency of excess withdrawal of this precious resource. The state of Punjab's agriculture is at low risk hence requires many strategies which would move the state's growth from a plateau phase to again an ever growing phase. Some of the strategies being eyed by the policy makers are diversification from the wheat-paddy rotation, reduction of the non-institutional loans, adoption of improved cultivation and increased production of oilseeds, pulses and other risky crops. Under the situation of risks and uncertainties in agriculture, a farmer hesitates to take decisions related to adoption of new technologies, cultural practices and use of adequate quantities of various costly inputs (Birari et al. 2002).

Hence, there is a need to stabilize and protect the farm economy through the adoption of various appropriate measures. One of the mechanisms that could alleviate their lot is the agricultural insurance. Thus agricultural insurance can be used as an important instrument of social and economic policy to be pursued by the state for the protection of farmers against unforeseen losses, to adapt to the effects of climate change and support the diversification of agriculture by encouraging the growing of more risky crops. The analysis of the farmers' perception and awareness towards crop insurance as a tool for risk management in Tamil Nadu was elicited by Kumar et al. (2011), and found that the farmers were aware about crop insurance and risk management measures implemented by the government. The awareness of crop insurance and risk management measures implemented by the government has been poor among the different farmers of Telangana State (Pandaraiah and Sashidar, 2015). About 80 per cent of the farmers do not have an awareness of crop insurance scheme. Awareness is endogenous to the decision to adopt, thus awareness and adoption are modelled jointly to allow us to interpret awareness as a potential policy variable which can be used to influence the probability of adoption (Morgenstern, 1996). Both the schemes PMFBY \& MWBCIS have not been implemented in the state of Punjab but there have been wide publicity of both the schemes at district level camps organised by the Krishi Vigyan Kendra (KVK) of Indian Council of Agricultural Research (ICAR). Keeping in view this study analyses the awareness level of these two schemes among the three stakeholders viz., scientists, extensionists and farmers.

\section{METHODOLOGY}

The respondents for the study were of three type viz; scientists, extensionists and farmers. The selection of the scientists was done from Punjab Agricultural University (PAU), Ludhiana. A total of 60 scientists were randomly selected as respondents of the study. A total of 30 extensionists were also selected randomly from the list of trainees of Punjab Agricultural Management and Extension Training Institute (PAMETI), Ludhiana during the last one year. And for the progressive farmers, the respondents were selected from the four farmers association of PAU viz. Progressive Beekeeper Association, Tree grower Association and PAU Kisan Club and Nursery Growers Association with 15 farmers randomly selected from each club or association, thus, making a total of 60 progressive farmers for the study. Thus in total a sample size of 150 respondents were selected for the study. The variable "awareness" refers to the exposure of the selected PAU scientists, extensionists and progressive farmers to various aspects of WBCIS and PMFBY such as scheme itself, insurance companies, risks covered, limit of coverage, procedure for assessment, processing, approval of claims etc. It was measured on dichotomous scale i.e. aware, not aware.

\section{RESULTS AND DISCUSSION}

\section{Awareness of Pradhan Mantri Fasal Bima Yojana (PMFBY) scheme among the PAU scientists, extensionists and farmers}

A perusal of data in Table 1 reveals that 68.33 per 
Table 1: Distribution of PAU scientists, extensionists and farmers according to their awareness regarding Pradhan Mantri Fasal Bima Yojana Schemes (PMFBY)

\begin{tabular}{|c|c|c|c|c|}
\hline S1. No. & Aspects & $\begin{array}{l}\text { Scientists } \\
(\mathrm{n}=60) *\end{array}$ & $\begin{array}{c}\text { Extensionists } \\
(\mathbf{n}=30) *\end{array}$ & $\begin{array}{l}\text { Farmers } \\
(\mathrm{n}=60) *\end{array}$ \\
\hline 1. & $\begin{array}{l}\text { Coverage of farmers: All farmers sharecroppers and } \\
\text { tenant farmers. }\end{array}$ & $41(68.33)$ & $13(43.33)$ & $23(38.33)$ \\
\hline 2. & Coverage of crops : & & & \\
\hline a. & Food crops (Cereals, Millets and Pulses) & $44(73.33)$ & $20(66.67)$ & $30(50)$ \\
\hline b. & Oilseeds & $33(55)$ & 19 (63.33) & $30(50)$ \\
\hline c. & Commercial / Horticultural Crops & $29(48.33)$ & $19(63.33)$ & $30(50)$ \\
\hline 3. & Risk coverage. & & & \\
\hline I. & Delayed Sowing / Planting Risk: & & & \\
\hline a. & Deficit rainfall & $32(53.33)$ & $17(56.67)$ & $25(41.67)$ \\
\hline b. & Adverse seasonal conditions & $24(40)$ & $19(63.33)$ & $26(43.33)$ \\
\hline II. & Standing Crop: & & & \\
\hline a. & Drought & $44(73.33)$ & $21(70)$ & $24(40)$ \\
\hline b. & Dry spells & $35(58.33)$ & $17(56.67)$ & $24(40)$ \\
\hline c. & Flood & $40(66.67)$ & $24(80)$ & $25(41.67)$ \\
\hline d. & Pests \& Diseases & $25(41.67)$ & $24(80)$ & $24(40)$ \\
\hline e. & Fire/Lightening & $21(35)$ & $19(63.33)$ & $25(41.67)$ \\
\hline f. & Storm/Hailstorm & $35(58.33)$ & $20(66.67)$ & $26(43.33)$ \\
\hline III. & Localized Calamities : & & & \\
\hline a. & Hailstorm & $32(53.33)$ & $17(56.67)$ & $22(36.67)$ \\
\hline b. & Landslide & $20(33.33)$ & $15(50)$ & $18(30)$ \\
\hline c. & Floods & $35(58.33)$ & $21(70)$ & $22(36.67)$ \\
\hline 4. & Post-harvest losses: Two weeks from harvest & $18(30)$ & $14(46.67)$ & $17(28.33)$ \\
\hline 5. & $\begin{array}{l}\text { Exclusion: Losses arising out of war and nuclear risks, } \\
\text { malicious damage and other preventable risks }\end{array}$ & $14(23.33)$ & $9(30)$ & $19(31.67)$ \\
\hline 6. & $\begin{array}{l}\text { Insurance unit: Village Panchayat or the major } \\
\text { growing crop unit. }\end{array}$ & $22(36.67)$ & $12(40)$ & $21(35)$ \\
\hline 7. & $\begin{array}{l}\text { Assessment of crop damage: due to post-harvest } \\
\text { losses and localized risks will be made on individual } \\
\text { farm basis. }\end{array}$ & $17(28.33)$ & $13(43.33)$ & $21(35)$ \\
\hline 8. & Sum insured (SI): & & & \\
\hline i. & $\begin{array}{l}\text { Sum insured is same for loanee and non-loanee } \\
\text { farmers. }\end{array}$ & $17(28.33)$ & $6(20)$ & $18(30)$ \\
\hline ii. & $\begin{array}{l}\text { The SI will be equal to the scale of finance as decided } \\
\text { by District Level Technical Committee (DLTC) or cost } \\
\text { of unit. }\end{array}$ & $21(35)$ & $6(20)$ & $17(28.33)$ \\
\hline iii. & $\begin{array}{l}\text { Sum insured is distributed among the critical phases } \\
\text { of the crop }\end{array}$ & $16(26.67)$ & $10(33.33)$ & $20(33.33)$ \\
\hline 9. & Premium rate: & & & \\
\hline a. & $\begin{array}{l}\text { Kharif - All food grains and Oilseeds crop }-2.0 \% \text { of } \\
\text { Sum Insured or Actuarial rate, whichever is less. }\end{array}$ & $22(36.67)$ & $17(56.67)$ & $26(43.33)$ \\
\hline b. & $\begin{array}{l}\text { Rabi-All food grains and Oilseeds crop }-1.5 \% \text { of Sum } \\
\text { Insured or Actuarial rate, whichever is less. }\end{array}$ & $23(38.33)$ & $16(53.33)$ & $26(43.33)$ \\
\hline c. & $\begin{array}{l}\text { Kharif and Rabi - Annual Commercial / Annual } \\
\text { Horticultural crops }-5 \% \text { of Sum Insured or Actuarial } \\
\text { rate, whichever is less. }\end{array}$ & $22(36.67)$ & $14(46.67)$ & $23(38.33)$ \\
\hline
\end{tabular}




\begin{tabular}{|c|c|c|c|c|}
\hline \multirow[t]{2}{*}{ S1. No. } & \multirow[t]{2}{*}{ Aspects } & $\begin{array}{c}\text { Scientists } \\
(\mathrm{n}=60) *\end{array}$ & $\begin{array}{l}\text { Extensionists } \\
\quad(\mathrm{n}=30) *\end{array}$ & $\begin{array}{l}\text { Farmers } \\
(\mathrm{n}=60) *\end{array}$ \\
\hline & & $f(\%)$ & $\mathrm{f}(\%)$ & $\mathrm{f}(\%)$ \\
\hline i. & $\begin{array}{l}\text { The premium subsidy shall be shared equally by center } \\
\text { and states. }\end{array}$ & $30(50)$ & $14(46.67)$ & $18(30)$ \\
\hline 12. & $\begin{array}{l}\text { Crop loans through KCC are covered under compulsory } \\
\text { coverage. }\end{array}$ & $18(30)$ & $12(40)$ & $18(30)$ \\
\hline 13. & $\begin{array}{l}\text { The sowing certificate for the crop insured is issued } \\
\text { by agriculture officer of the block. }\end{array}$ & $16(26.67)$ & $12(40)$ & $16(26.67)$ \\
\hline
\end{tabular}

* multiple responses.

cent of PAU scientists 43.33 per cent of extensionists and 38.33 per cent of progressive farmers were aware regarding the coverage of all farmers including sharecroppers and tenant farmers. The scheme covers all the food crops, oilseeds and horticultural crops. It is interesting to note that half of the farmers were aware of it. A little less than three-fourth $(73.33 \%)$ of the PAU scientists were aware that the cereals, millets and pulses were covered under PMFBY whereas 55 per cent and 48.33 per cent of them were aware of coverage of oilseeds and horticultural crops respectively. Majority of the extensionists were aware that food crops were covered under the scheme. The table further reveals that equal percentage of 63.33 was aware of the coverage of oilseeds and horticultural crops. Among the three stakeholders, the awareness of the coverage of crops under the scheme was almost equal, with little variation.

The risk covered under PMFBY referred to the delayed sowing due to deficit in rainfall and adverse weather condition. The risks to the standing crops are drought, dry spells, flood, pests \& diseases, fire and storm which were covered under the scheme. The localized calamities caused due to hailstorm, landslide, floods and post-harvest losses up to two weeks from harvest are also covered under the scheme. The awareness of all the three stakeholders regarding these aspects has been presented in the Table 1. A perusal of this table reveals that almost half of the PAU scientists, extensionists (53.33\% and $56.67 \%$ ) were aware that the deficit of rainfall causing delay in sowing is covered under the scheme, whereas 41.67 per cent of the farmers were aware of it. About 63.33 per cent of the extensionists were aware of the risk coverage of prevented sowing due to adverse seasonal conditions under PMFBY, whereas equal percentage (40\% and 43.33 $\%)$ of scientists and farmers were aware of this aspect. Among all the stakeholders the extensionists were comparatively more aware about the risk coverage of prevented sowing, than the scientists and farmers.

The coverage of risks to the standing crops due to drought, dry spells, flood, pests and diseases, fire, hailstorm aspects of PMFBY's awareness was comparatively more among the extensionists. The findings given in Table 1 further reveal that majority of the extensionists ( $80 \%$ ) were aware about the risk coverage from pest and diseases attack and flood whereas 70 per cent of the extensionists were aware of risk coverage from drought. The data further reveal that almost three fifth of the extensionists (63.33\% and $66.67 \%)$ were aware about the risk coverage from fire/lightening and storm/hailstorm for the standing crop under PMFBY where 56.67 per cent of the extensionists were aware about the risk coverage of dry spell for the standing crops.

But it is interesting to note from the data that almost 40 per cent of the farmers were aware about the risk coverage of drought, dry spells, flood, pest and disease attack, fire, hailstorm. The post-harvest losses caused up to two weeks from harvest was covered under PMFBY, had awareness among little less than half of the extensionists (46.67\%), 
whereas almost equal percentage of farmers and PAU scientists were aware about it.

The awareness of the exclusions of the scheme was low since only a meagre percentage of $23.33,30$ and 31.67 of scientists, extensionists and farmers were aware respectively. Only 36.67, 40 and 35 percentage of PAU scientists, extensionists and farmers were aware about the notification of village panchayat as an insurance unit. Even the loss/ crop damage assessment on individual farm basis feature of PMFBY had low awareness among all the three stakeholders, figuring to 28.33 per cent, 43.33 per cent and 35 per cent among PAU scientists, extensionists and farmers respectively.

The awareness of different aspect of Sum Insured (SI) for the insurance under PMFBY is also low among all the stakeholders, since the data presented in the table reveal that only 28.33 per cent, 20 per cent and 30 per cent of PAU scientists, extensionists and farmers were aware that SI is same for loanee and non-loanee farmers. The amount of SI will be equal to the scale of finance as decided by DLTC also had low awareness since $35 \%, 20 \%$ and $28.33 \%$ of PAU scientists, extensionists and farmers were aware of it. Further the table also reveals that as low as $26.67 \%$ of PAU scientists and equal percentage of extensionists and farmers $(33.33 \%)$ were aware the SI is distributed among the critical phases of the crop.

The premium rate for kharif crops is affixed at $2.0 \%$ of SI and $1.5 \%$ for rabi crops where as for the horticultural crops it is 5.0 per cent of SI. The data presented in Table 2 related to this aspect reveals that majority of the extensionists (53.33\%) were aware of this whereas the almost two fifth of $(38.33 \%)$ PAU scientists were aware of it. Almost 40 per cent of the farmers were aware regarding the premium rate.

The subsidy provided in the premium is shared equally by centre and state governments and the additional subsidy is borne by the state. Majority of the PAU scientists s and extensionists $(50 \%$ and $46.67 \%$ ) were aware about this aspect, where as only 30 per cent of the farmers were aware about it. The processing of the claims and the payment process is of 45 days period. About 43.33 per cent of extensionists were aware of this whereas only 35 per cent of PAU scientists were aware of it. A meagre, twenty five per cent of the farmers were aware of it. An important aspect related to the implementation of PMFBY is the issuing of the sowing certificate for the crop insured is done by the agriculture officer of the block. Majority of the extensionists were aware (40 per cent) of this whereas equal percentage $(26.67 \%)$ of the PAU scientists and farmers were aware about it. The awareness of the aspect that mobile app are used for reporting incidents of localized risks was among almost equal percentage of extensionists and farmers $(26.67 \%$ and $28.33 \%)$ where as 35 per cent of scientists s were aware of this aspect.

\section{Awareness of Weather Based Crop Insurance Scheme (WBCIS) among the PAU scientists, extensionists and farmers}

A perusal of data in Table 2 reveals that 68.33 per cent of PAU scientists, 43.33 per cent of extensionists and 38.33 per cent of progressive farmers were aware regarding the coverage of all farmers including sharecroppers and tenant farmers. The scheme covers all the food crops, oilseeds and horticultural crops. It is interesting to note that half of the farmers were aware of it. A little less than three fourth $(73.33 \%)$ of the PAU scientists $\mathrm{s}$ were aware that the cereals, millets and pulses were covered under WBCIS, where as 55 per cent and 48.33 per cent of them were aware of coverage of oilseeds and horticultural crops respectively. The data put forth in Table 2 also reveals that majority of the extensionists were aware that food crops were covered under the scheme. The table further reveals that equal percentages of 63.33 were aware of the coverage of oilseeds and horticultural crops. Among the three stakeholders the awareness of the coverage of crops under the scheme was almost equal, with little variation.

The weather perils covered under WBCIS referred to two different kind viz., normal coverage and add on index. Under the normal coverage the deficit in rainfall excess, unseasonal, dry spell and dry days. The variation in, the add-on index covered the losses due to hail storms and cloud bursts. The notification of the scheme is issued at least one month prior to commencement of crop season and contains the details viz; crops \& Reference Unit Area (RUA), sum insured, premium rate, subsidy and weather station for each RUA covered under the 
Table 2: Distribution of PAU scientists, extensionists and farmers according to their awareness regarding Weather Based Crop Insurance Schemes (WBCIS)

\begin{tabular}{|c|c|c|c|c|}
\hline \multirow{2}{*}{$\begin{array}{l}\text { Sl. } \\
\text { No. }\end{array}$} & \multirow[t]{2}{*}{ Aspects } & $\begin{array}{l}\text { Scientists } \\
(\mathrm{n}=60)^{*}\end{array}$ & $\begin{array}{c}\text { Extensionists } \\
(\mathrm{n}=30)^{*}\end{array}$ & $\begin{array}{c}\text { Farmers } \\
(\mathrm{n}=60)^{*}\end{array}$ \\
\hline & & $f(\%)$ & $f(\%)$ & $f(\%)$ \\
\hline 1. & $\begin{array}{l}\text { Coverage of farmers: All farmers including sharecroppers } \\
\text { and tenant farmers }\end{array}$ & $41(68.33)$ & $13(43.33)$ & $23(38.33)$ \\
\hline 2. & Coverage of crops: & & & \\
\hline a. & Food crops (Cereals, Millets and Pulses) & $44(73.33)$ & $20(66.67)$ & $30(50)$ \\
\hline b. & Oilseeds & $33(55)$ & $19(63.33)$ & $30(50)$ \\
\hline c. & Commercial / Horticultural Crops & $29(48.33)$ & $19(63.33)$ & $30(50)$ \\
\hline 3 & Weather perils covered. & & & \\
\hline I. & Normal coverage. & & & \\
\hline a. & Rainfall:- & & & \\
\hline i. & Deficit & $42(70)$ & $23(76.67)$ & $21(35)$ \\
\hline ii. & Excess & $37(61.67)$ & $21(70)$ & $21(35)$ \\
\hline iii. & Unseasonal & $26(43.33)$ & $17(56.67)$ & $20(33.33)$ \\
\hline iv. & Dry spell & $31(51.67)$ & $17(56.67)$ & $22(36.67)$ \\
\hline $\mathrm{v}$. & Dry days & $22(36.67)$ & $17(56.67)$ & $23(38.33)$ \\
\hline b. & Temperature:- & & & \\
\hline i. & High & $29(48.33)$ & $22(73.33)$ & $18(30)$ \\
\hline ii. & Low & $27(45)$ & $18(60)$ & $18(30)$ \\
\hline II. & Add on index plus: & & & \\
\hline i. & Hail storms & $36(60)$ & $15(50)$ & $23(38.33)$ \\
\hline ii. & Cloud bursts & $19(31.67)$ & $12(40)$ & $23(38.33)$ \\
\hline 4. & Risk period is from sowing to maturity of crop. & $36(30)$ & $18(60)$ & $18(30)$ \\
\hline 5. & $\begin{array}{l}\text { Notification of the scheme: The issuance is one month } \\
\text { prior to commencement of crop season or risk period. }\end{array}$ & $13(21.67)$ & $9(30)$ & $17(28.33)$ \\
\hline a. & The notification contains the following details: & & & \\
\hline i. & Crops \& Reference Unit Areas (RUA) & $21(35)$ & $10(33.33)$ & $16(26.67)$ \\
\hline ii. & Sum Insured (SI) & $25(41.67)$ & $10(33.33)$ & $18(30)$ \\
\hline iii. & Premium rate & $26(43.33)$ & $12(40)$ & $17(28.33)$ \\
\hline iv & Subsidy & $17(28.33)$ & $17(56.67)$ & $18(30)$ \\
\hline $\mathrm{v}$. & Reference Weather Station & $17(28.33)$ & $6(20)$ & $19(31.67)$ \\
\hline 6. & Sum insured (SI) : & & & \\
\hline i. & Sum insured is same for loanee and non-loanee farmers. & $17(28.33)$ & $6(20)$ & $18(30)$ \\
\hline ii. & $\begin{array}{l}\text { The SI will be equal to the scale of finance as decided by } \\
\text { District Level Technical Committee (DLTC) or cost of unit. }\end{array}$ & $21(35)$ & $6(20)$ & $17(28.33)$ \\
\hline iii. & $\begin{array}{l}\text { Sum insured is distributed among the critical phases of } \\
\text { the crop. }\end{array}$ & $16(26.67)$ & $10(33.33)$ & $20(33.33)$ \\
\hline 7. & Premium rate: & & & \\
\hline a. & $\begin{array}{l}\text { Kharif-All food grains and Oilseeds crop }-2.0 \% \text { of Sum } \\
\text { Insured or Actuarial rate, whichever is less. }\end{array}$ & $22(36.67)$ & $17(56.67)$ & $26(43.33)$ \\
\hline b. & $\begin{array}{l}R a b i-\text { All food grains and Oilseeds crop }-1.5 \% \text { of Sum } \\
\text { Insured or Actuarial rate, whichever is less. }\end{array}$ & $23(38.33)$ & 16 (53.33) & $26(43.33)$ \\
\hline c. & $\begin{array}{l}\text { Kharif and Rabi-Annual Commercial / Annual } \\
\text { Horticultural crops - } 5 \% \text { of Sum Insured or Actuarial rate, }\end{array}$ & $22(36.67)$ & 14 (46.67) & $23(38.33)$ \\
\hline
\end{tabular}
whichever is less. 


\begin{tabular}{|c|c|c|c|c|}
\hline \multirow[t]{2}{*}{$\begin{array}{l}\text { S1. } \\
\text { No. }\end{array}$} & \multirow[t]{2}{*}{ Aspects } & $\begin{array}{l}\text { Scientists } \\
(\mathrm{n}=60)^{*}\end{array}$ & $\begin{array}{l}\text { Extensionists } \\
\quad(\mathrm{n}=30)^{*}\end{array}$ & $\begin{array}{c}\text { Farmers } \\
(\mathrm{n}=60)^{*}\end{array}$ \\
\hline & & $f(\%)$ & $f(\%)$ & $f(\%)$ \\
\hline 8. & Premium subsidy: & & & \\
\hline i. & $\begin{array}{l}\text { The premium subsidy shall be shared equally by center } \\
\text { and states. }\end{array}$ & $30(50)$ & $14(46.67)$ & $18(30)$ \\
\hline ii. & Additional subsidy shall be entirely borne by the state. & $21(35)$ & $12(40)$ & $17(28.33)$ \\
\hline 9. & $\begin{array}{l}\text { Claims shall be assessed on the basis of weather data } \\
\text { recorded by Reference Weather Station. }\end{array}$ & $33(55)$ & $15(50)$ & $17(28.33)$ \\
\hline 10. & $\begin{array}{l}\text { The claims will be processed and paid within } 45 \text { days } \\
\text { from the end of risk period. }\end{array}$ & $21(35)$ & $10(33.33)$ & $15(25)$ \\
\hline
\end{tabular}

*multiple responses.

scheme. The awareness of all the three stakeholders regarding these aspects has been presented in the Table 2. A perusal of this table reveals that the majority of the PAU scientists and extensionists (70 $\%$ and $76.67 \%$ ) were aware that the deficit rainfall is covered under the scheme, whereas 35 per cent of the farmers were aware of it. While little more than three-fourth of the scientists were aware of excess rainfall being covered under WBCIS, 70 per cent of extensionists were also aware of it. About 56.67 per cent of the extensionists were aware that unseasonal rainfall is covered under WBCIS, where as about 43.33 per cent and 33.33 per cent of scientists and farmers were aware about this coverage. The coverage of damage caused due to dry spells and dry days of WBCIS, had awareness among 56.67 per cent of extensionists where as almost two fifth of the farmers were aware about it. Almost half of the PAU scientists were aware that dry spell coverage is there under WBCIS but 36.67 per cent of them were aware that dry days are also covered. About 30 per cent of the farmers were aware that the damage to crops caused due to temperature variation is under the ambit of WBCIS. Majority of the extensionists (73.33\%) were aware of this temperature aspect under normal coverage but only half of the scientists were aware of it. The awareness of the add on coverage of hailstorms and cloud bursts was known to 38.33 per cent of farmers and almost half of the extensionists were aware of it. But 60 per cent of PAU scientists were aware that hailstorms were under the ambit of WBCIS and 31.67 per cent were aware about the cloud burst coverage. The notification of the scheme and the details of it, concerning RUA, SI, Premium rate, Subsidy, RWS is an important aspect of the scheme.
The data put forth in Table 2 reveals that almost three fifth of the farmers were aware regarding the notification aspect. Where as the subsidy details of the notification has awareness among almost half of the extensionists.

A perusal of the data further reveals that almost two fifth of the extensionists were aware of other details put up in the notification. Comparatively PAU scientists are less about this aspect, since almost 30 per cent of them were aware of the details viz; premium rate, subsidy, RUA crops. About 30 per cent of the farmers were aware that sum insured is same for loanee and non loanee farmers. The data put forth in Table 2 also reveal that almost 30 per cent of the extensionists were aware that SI is equal to the scale of finance decided by DLTC and is distributed among the critical phases of the crop. About 20 per cent of the extensionists were aware about the SI being equal for both loanee and non loanee farmers; also SI being equal to the scale of finance as decided by DLTC. Where as 33.33 per cent of extensionists were aware that SI is distributed among the critical phases of the crop. Almost 30 per cent of PAU scientists were aware about the aspect. The premium rate for kharif crops is fixed at $2.0 \%$ of SI and $1.5 \%$ for rabi crops where as for horticultural crops it is 5.0 per cent of SI. The data presented in Table 2 related to this aspect reveals that majority of the extensionists (53.33\%) were aware of this whereas the almost two fifth of $(38.33 \%)$ PAU scientists were aware of it. Almost 40 per cent of the farmers were aware regarding the premium rate. The subsidy provided in the premium is shared equally by centre and state governments and the additional subsidy is borne by the state. Majority 
Table 3: Distribution of scientists, extensionists and farmers according to their overall awareness level regarding PMFBY

\begin{tabular}{|c|c|c|c|c|}
\hline S1. No. & PMFBY & $\begin{array}{l}\text { Scientists } \\
(n=60) f(\%)\end{array}$ & $\begin{array}{c}\text { Extensionists } \\
(n=30) \text { f }(\%)\end{array}$ & $\begin{array}{c}\text { Farmers } \\
(n=60) \text { f }(\%)\end{array}$ \\
\hline 1 & Low $(0-11)$ & $23(38.33)$ & $6(20)$ & $36(60)$ \\
\hline 3 & High (22-33) & $13(21.67)$ & $9(30)$ & $17(28.33)$ \\
\hline
\end{tabular}

Table 4: Distribution of PAU scientists, extensionists and farmers according to their overall awareness level regarding WBCIS

\begin{tabular}{ccccc}
\hline S1. No. & WBCIS & $\begin{array}{c}\text { Scientists } \\
(\mathbf{n = 6 0 )} \mathbf{f}(\mathbf{\%})\end{array}$ & $\begin{array}{c}\text { Extensionists } \\
(\mathbf{n = 3 0 )} \mathbf{f}(\mathbf{\%})\end{array}$ & $\begin{array}{c}\text { Farmers } \\
(\mathbf{n}=\mathbf{6 0 )} \mathbf{f}(\mathbf{\%})\end{array}$ \\
\hline 1 & Low (0-10) & $22(36.67)$ & $9(30)$ & $36(60)$ \\
2 & Medium (10-20) & $23(38.33)$ & $13(43.33)$ & $9(15)$ \\
3 & High (20-30) & $15(25)$ & $8(26.67)$ & $15(25)$ \\
\hline
\end{tabular}

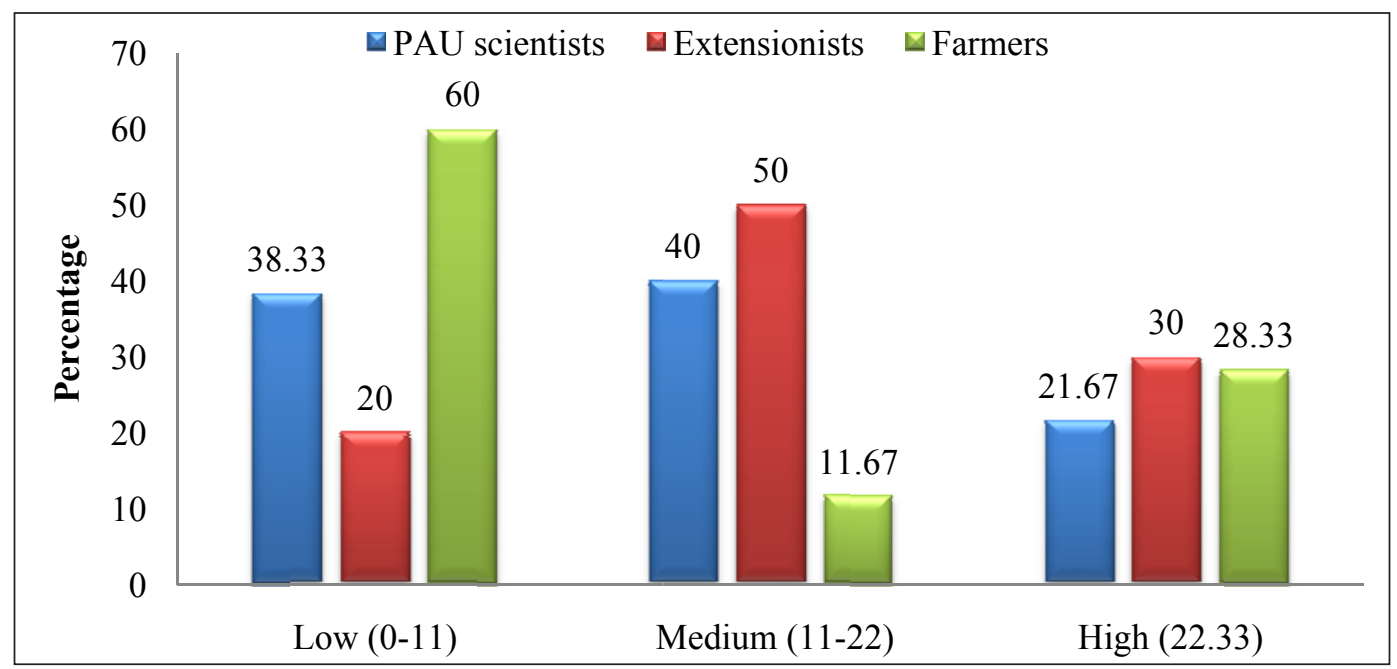

Fig. 1: Distribution of scientists, extensionists and farmers on the basis of their level of awareness PMFBY

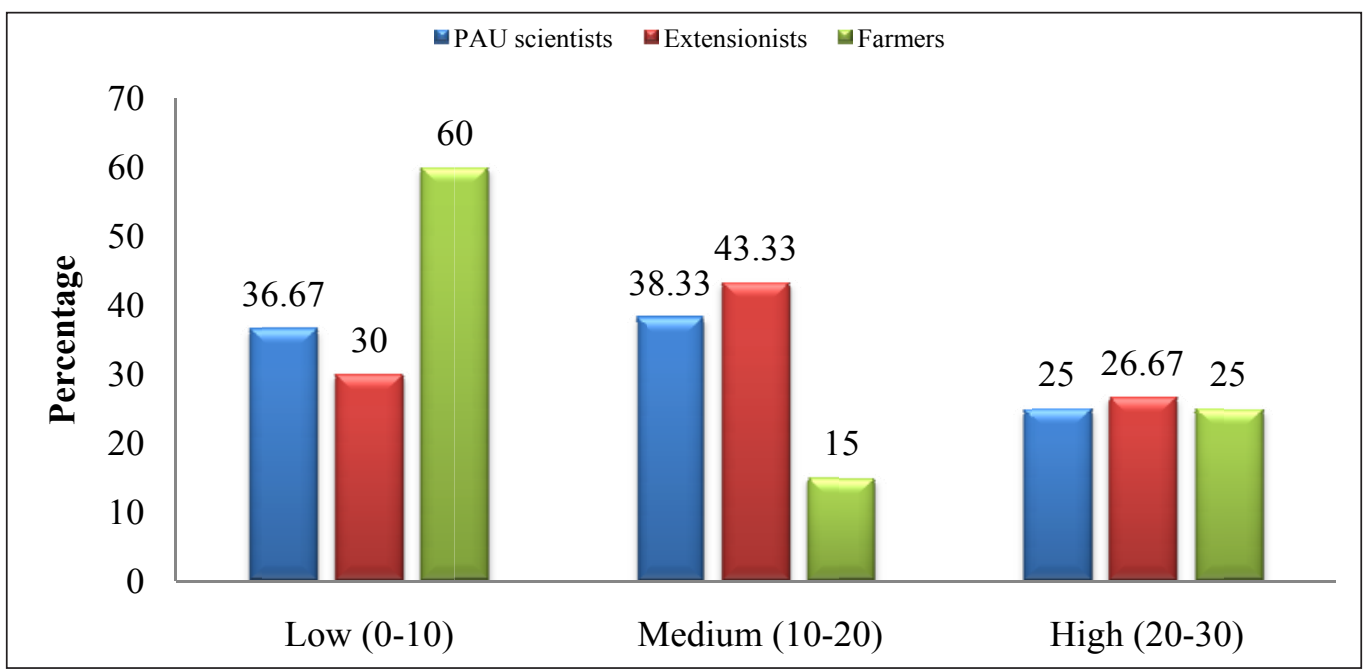

Fig. 2: Distribution of scientists, extensionists and farmers on the basis of their level of awareness WBCIS 
of the PAU scientists and extensionists (50\% and $46.67 \%$ ) were aware about this aspect, where as only 30 per cent of the farmers were aware about this aspect where as the awareness of the assessment of claims on the basis of weather data recorded by Reference Weather Station was among 55 per cent of scientists where as only 50 per cent of extensionists were aware of it. A meagre, 28.33 per cent of the farmers were aware of this aspect. The processing of the claims and the payment process is of 45 days period. About 33.33 per cent of extensionists were aware of this where as only 35 per cent of PAU scientists were aware of it. A meagre twenty five per cent of the farmers were aware of it.

\section{Overall awareness level of the Pradhan Mantir Fasal Bima Yojana (PMFBY), among the PAU scientists, extensionists and farmers}

The respondents were categorized into three groups according to their awareness level. The data in Table 3 reveals that 38.33 per cent, 20 per cent and 60 per cent of the PAU scientists, extensionists and farmers had low level of awareness while 40 per cent, 50 per cent and 11.67 per cent of them had medium level of awareness respectively. Also 21.67 per cent, 30 per cent and 28.33 per cent of PAU scientists, extensionists and farmers had high level of awareness regarding the various aspects of Pradhan Mantri Fasal Bima Yojana (PMFBY) respectively.

\section{Overall awareness level of the Weather Based Crop Insurance Scheme (WBCIS) among the PAU scientists, extensionists and farmers}

The respondents were categorized into three groups according to their awareness level. The data in Table 4 reveals that 36.67 per cent, 30 per cent and 60 per cent of the PAU scientists, extensionists and farmers had low level of awareness while 38.33 per cent, 43.33 per cent and 15 per cent of them had medium level of awareness respectively. Also 25 per cent, 26.67 per cent and 25 per cent of PAU scientists, extensionists and farmers had high level of awareness regarding Weather Based Crop Insurance Scheme (WBCIS) respectively.

The awareness level of PMFBY among all the stakeholders is comparatively more than WBCIS which may be due to its wide popularization when being launched by the GOI. Though WBCIS is an older scheme than PMFBY and its implementation was limited to few districts of Punjab state during 2008-09 (Ludhiana, Sangrur, Gurdaspur, Fatehgarh Sahib) its awareness level was comparatively lower than PMFBY among the PAU scientists, extensionists and farmers.

\section{CONCLUSION}

Majority of the scientists were aware about of the features of PMFBY\& WBCIS like coverage of crop, risk coverage whereas less aware about the post-harvest coverage losses only 37 percentage of scientists $\mathrm{s}$ were aware about the insurance unit to be village panchayat where as 28 percentage of scientists were aware that the sum insured in same for loanee and non loanee farmers and similar trend of awareness was also found for the extensionists. Regarding the farmer's awareness about of the features of PMFBY like coverage of crop, risks coverage, post-harvest coverage and premium subsidy was relatively low as compared to scientists and extensionists. The progressive farmers being considered to have more of awareness have been the sample of the study. The data reveals that almost more than half of the progressive farmers were aware regarding the various aspects of PMFBY. There is a need to make the famers aware about crop/weather insurance through awareness programme. Insurance education can be incorporated into various training programmes organized on risk management.

\section{REFERENCES}

Anonymous. 2010. Intense heat wave affects wheat production in Punjab. The Hindu, April 22, 2010.

Birari, K.S., Nawadkar, D.S. and Kassar, D.V. 2002.Crop insurance scheme as livelihood security in rainfed agriculture in Western Maharashtra. Agricultural Economics Research Review, 15: 63-69.

Biswas, B., Dhaliwal, L.K., Singh, S.P. and Chaha, S.K.2009. Weather based crop insurance in India: Present status and future possibilities Journal of Agrometerology, 11: 65-72.

Rao, K.N. and Bockel, L. 2008. Risk Management as a Pillar in Agriculture and Food Security Policies - India Case Study Policy Brief, On-line resource materials for policy making, FAO, Rome.

Kumar, D.S., Barah, B.C., Ranganathan, C.R., Venkatram, R., Gurunathan, S. and Thirumoorthy, S. 2011. An analysis of farmers' perception and awareness towards crop insurance as a tool for risk management in Tamil Nadu. Agricultural Economics Research Review, 24: 37-46. 
AESRA

Wahab Zada et al.

Morgenstern, R.D. 1996. Does the provision of free technical information really influence firm behaviour. Discussion Paper 96-16. Retrieved from https:/www.rff.org/publications/ journal-articles/does-the-provision-of-free-technicalinformation-really-influence-firm-behavior/ on 12-082018.
Pandaraiah, G. and Sashidar, K.V. 2015.Crop Insurance Farmers perception and awareness. International Journal of Economics and Business Research, 3: 2347-49. 